\title{
Food Is Security: The Nexus of Health Security in Fragile and Failed States
}

\author{
John Quinn1, Tomas Zeleny2,3, Vladimir Bencko3 \\ ${ }^{1}$ Prague Center for Global Health, Institute of Hygiene and Epidemiology, First Faculty of Medicine, Charles \\ University in Prague, Prague, Czech Republic \\ ${ }^{2}$ Institute of Economic Studies, Faculty of Social Sciences, Charles University in Prague, Prague, Czech Republic \\ ${ }^{3}$ Institute of Hygiene and Epidemiology, First Faculty of Medicine, Charles University in Prague, Prague, \\ Czech Republic \\ Email: john.quinn@If1.cuni.cz, Tomas.z@gmail.com, zeleny.t@gmail.com, vladimir.bencko@lf1.cuni.cz
}

Received 18 August 2014; revised 6 September 2014; accepted 13 September 2014

Copyright (C) 2014 by authors and Scientific Research Publishing Inc.

This work is licensed under the Creative Commons Attribution International License (CC BY).

http://creativecommons.org/licenses/by/4.0/

(c) (i) Open Access

\section{Abstract}

Global food security is a major development challenge dictated by state stability, resilience to geopolitical and economic shocks and is linked to health security. Fragile and failed nation-states are at risk of extreme poverty and lead to war and conflict. Fragile states experience, corrupt financial regimes and are influenced by skewed global market systems and reduced equitable market access that decrease food and health security. This qualitative review describes the critical cross sections of food security, the influence of global market systems and state stability and institutions that form the nexus of global health security. We outline how the manipulation of free market systems and decreased state capacity not only decrease food and health security but also contribute to state fragility and failure. Improved public health policy mechanisms, decreased dependence on foreign financial structures and extractive mechanisms are crucial to improving food and health security at present, and to further increase state stability in the future.

\section{Keywords}

Food Security, Health Security, Human Security, Malnourishment, Starvation, Food Economics

\section{Introduction}

Access to food defines food security. Fragile and failed states lack infrastructure or mechanisms that enable health for its citizens. Fragile and failed states lack duty of care, no mandate and hold no viable written or unwritten contract with their citizens to offer security or inclusive state services that engender a wider notion of 
public health. Manipulation of free market systems and foreign financial structures coupled with low state capacity to solve complex social and economic concerns lead to a systemically destabilized state, subsequent deficient food and health security. Improved food security is inherently linked to empowerment of state government and institutions to create equitable, sustainable and durable policies that decrease health disparities, foster economic sovereignty and improve food security. In this qualitative review, we hypothesize that state fragility and failure is directly linked to food insecurity and subsequent global health security.

We utilize the Failed State Index (FSI) from the Fund for Peace and the new Global Food Security Index (GFSI) from the Economist Intelligence Unit to examine the relationship and interaction with food security against food security markers within fragile and failed states. With this, we examined a variety of factors associated with food security including food systems, state stability, nutritional access, market manipulation, the recent commoditization of food, financial products and risk, influence of food aid programs, food pricing policy, institutional capacity, environmental integrity and climate change. Finally, we offer simple policy recommendations to improve food security among failed and fragile states specific to nation-state institutional capacity and resuscitation.

\section{Background}

The character of food systems, food policy and global food security are changing with global paradigm shift of a post unipolar moment, increased urbanization and myriad migration flows trans-border. In the post-Westphalian and post-Cold War era, multiple state actors influence regional and global order through previously unconventional means of regional small-scale conflict that often have large scale global impact [1] [2]. In certain cases, small-scale regional conflict was exacerbated by globally connected commerce, ease of wanton financial products and transactions, social movements (i.e. ongoing effects of the Arab Spring and financial crisis), increased incidence of non-communicable disease (NCDs) and endemic infectious disease across pervious state borders. The Middle East and North Africa experienced a dramatic price rise of bread and cereals [3] before the initial riots and social-political uproar that occurred in 2010-2011, sparking a regional movement and crisis presently still underway and destabilizing the region further. With this global flux, resource poor communities have easy access to low-cost processed foods, which lack nutritional value and directly influence non-communicable disease (i.e. obesity, heart disease, diabetes and cancer). NCDs may be experiencing a global burst in incidence that is yet to be described.

Fragile and failed states pose a direct and continued threat to food security and global health. Famine and financial markets that influence food are human products. By framing the issue into a state health framework, evidenced based solutions for food and health insecurity that predominate fragile and failed nation-states can be considered. For the purposes of this paper, we define a fragile or failed state as one that lacks capacity to promote food security through market access and where citizens and the state cannot provide resilient food systems that weather major shocks (i.e. price variability, poor crop years or irreversible environmental degradation). Pestilence and drought occur due to nature and climate change. Famine and extractive government institutions are created and maintained by people. We propose that by increasing the presence of inclusive state institutions and implementation of healthy public policies, state stability can improve and be resuscitated from fragility, which in turn can provide a positive feedback loop to improving food security and subsequent health security. We propose that preventing state failure offers improved health security.

The purpose of this paper is to provide evidence that on the continuum of stability and health security, a decrease in food and health security, antagonizes and further destabilizes state fragility. This descriptive qualitative review attempts to unpack this causal link between state fragility, health and food security. This positive feedback loop is illustrated in Figure 1.

Within a globalized economy where borders are more porous and both human and financial capital may flow easier, food is as critical to national security as resources such as oil, steel, rubber, water and other raw materials. However, access to a consistent food supply provides the minimum level of human and health security. Food is security and the ability of a state to provide basic infrastructure and free market access to purchase affordable, sustainable and nutritious food is a key state role; the inability to do this is a mark of the state failure. A state holds the duty of care to provide an environment that encourages human and health security for its citizens.

Conflict and food security are inextricably connected. It is well established that countries and communities that experience active conflict are at an increased risk of food insecurity, and subsequent decreased health and 
human security [4]. The authors have accumulated a simple factor-consequence table to better illustrate specific challenges affecting food security in fragile and failed states. Determining factors of human conflict that affect food security are summarized in Table 1 .

\subsection{Health, Human and Food Security in Context}

Food as an element of health security is not a forgone conclusion and must be placed within the framework of public health policy. In this review, we propose that health security, human security, economic security and sustainable nation-state stability comprise the nexus of human development.

To remain within the framework and context of global health, development, and public health, we hold the definition of health security as the access to essential health services, disease prevention and protection from environmental and behavioral risks as supported by the literature [6] [7]. This definition frames health security as an aspect of human security, which is the "freedom from want", and access to life saving clinical and public health interventions [8]. Plainly, health and human security converge into the adequate access to basic public health, healthcare resources, social inclusion and protection.

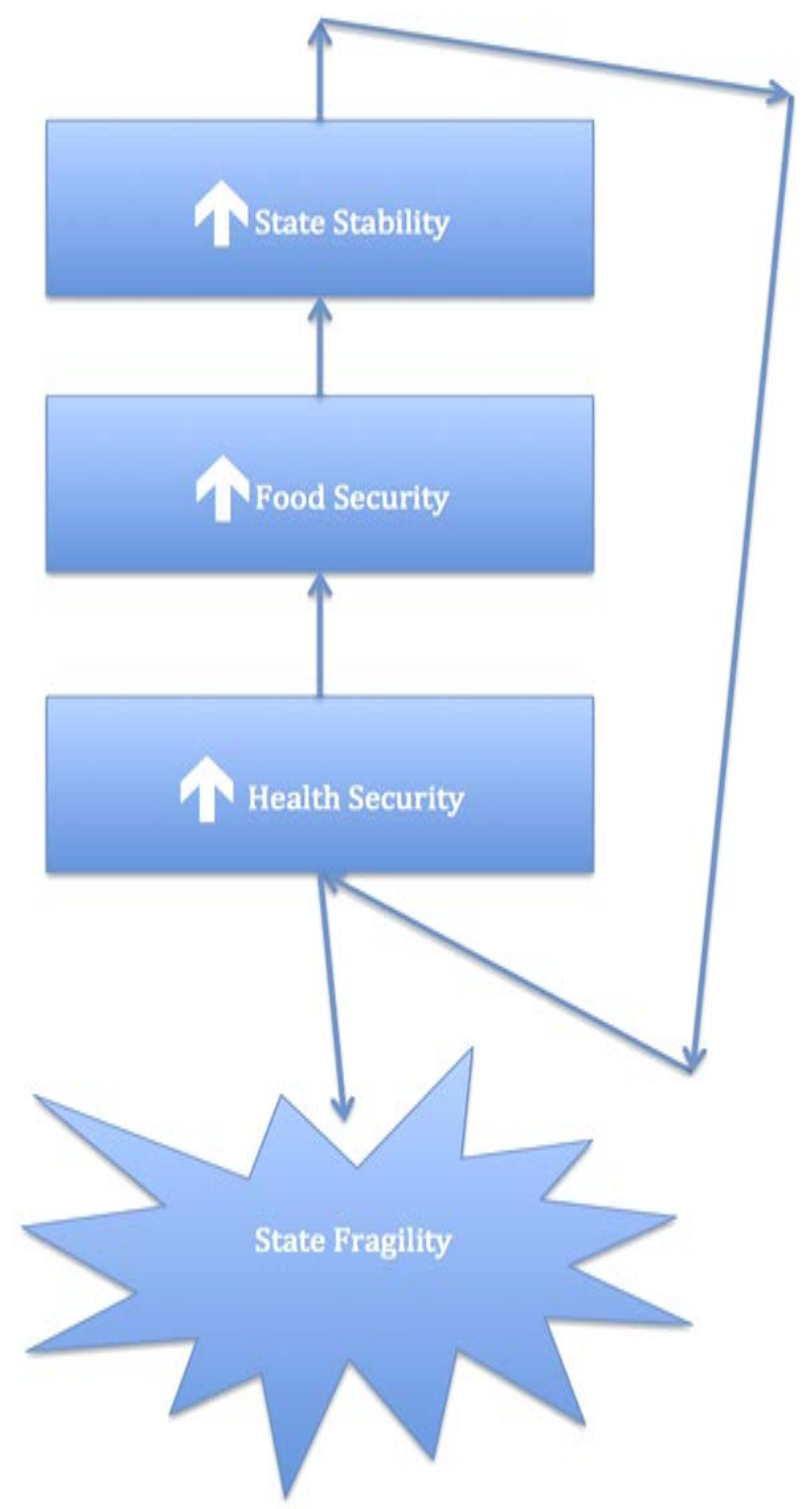

Figure 1. The positive feedback loop of stability. 
Table 1. Factors of human conflict that affect food security.

\begin{tabular}{|c|c|}
\hline Key Factor & Consequence \\
\hline Access to food, equitable and consistent markets & Price shocks and price variability lead to supply disruption \\
\hline Rural and agricultural infrastructure destroyed & A decrease in local supply and disruption in food distribution networks \\
\hline Loss of livestock and access to arable land & Decrease in yields and caloric availability \\
\hline $\begin{array}{l}\text { Deforestation, desertification coupled with rising } \\
\text { coastal levels and decreasing potable water tables }\end{array}$ & $\begin{array}{l}\text { Climate change disruption of food availability, natural resource depletion } \\
\text { and access to water for consumption }\end{array}$ \\
\hline $\begin{array}{l}\text { No consistent access to quality seed, farm technology } \\
\text { or human capital }\end{array}$ & Cycle of poverty with poor access to basic technology and high yield seed \\
\hline $\begin{array}{l}\text { Migration and human flow: large influx of people } \\
\text { into one region, out of another region }\end{array}$ & Market shock, rapid increase in food demand and price variability \\
\hline $\begin{array}{l}\text { The use of landmines and other explosive } \\
\text { devices throughout arable land }\end{array}$ & Reduction in arable land access, increased risk of injury or death \\
\hline The use of food as a weapon & $\begin{array}{l}\text { When food resources and access are in scarcity, coercion of communities } \\
\text { and populations can ensue [5] }\end{array}$ \\
\hline
\end{tabular}

More specifically, health security includes protection against emerging infectious disease; violence, conflict and natural disasters [9]-[11]. It should be noted that there is no clear causal link between infectious disease and that of state fragility or failure, increased infectious disease does not necessarily lead to violence or state collapse [12]. However, we propose that any reduction in state supported healthcare infrastructure and access to disease prevention can reduce best health outcomes, reduce quality of care and leads to a reduction in health security. And as stated earlier, NCDs are an added concern to budding fragile states with an increased burden of disease in the developing word. Economic strife and conflict threatens health security and can lead to an increase in infectious disease, trauma, mental illness, malnourishment and a reduction in food security with a decrease in state capacity [13]-[17].

By definition, fragile states often exhibit geographical isolation from a port or trade access, experience physical and economic constraints, a reduction in institutional capacity, corruption at high office, nepotism, external threat and lack of food and health security [18] [19]. Governments often lose their duty of care for citizens, and the state becomes illegitimate to its citizens [20]-[24]. Food insecurity for citizens in fragile or failed states is characterized through chronic hunger, malnourishment and subsequent disease, which exhibit increased incidence and prevalence throughout fragile states. Within fragile and failed states, private non-state actors have gained influence to that of conflict and control of violence; many of which have less focus on responsibility for the greater good such as provision of food security [25].

Economic security is a nation-state's ability to follow its own policies to develop the national economy and to globally compete. On a citizen level, economic security is having access to work, financial resources and or income to support a consistent standard of living - to include financial solvency, future access to work and cash flow.

\subsection{State Fragility and Failure}

All states are vulnerable to disaster, war, market shock and disruption to state institutional capacity; however we propose that states ability to buffer these shocks determines whether they are fragile or failing. As found in medicine, prevention is a far more cost effective and efficient treatment modality than is acute treatment of disaster. Preventing states from failing and resuscitating those fragile states or states already in failure is a strategic, financial and moral imperative to ensure food and health security. Global financial structure and market systems do not create conditions that support fragile states or their capacity to govern. While global reform to these systems is unlikely, the results of this review conclude that aid and development efforts to improve food security in fragile and failed states should focus on strengthening state institutions, public health infrastructure and making market systems able to weather major financial and economic shock and market uncertainty.

\subsubsection{Failed State Index (FSI) in Context}

The Fund for Peace publishes the annual Failed States Index (FSI) assessing all countries on the pressures they 
experience and ultimately the metrics associated to the susceptibility of state failure in aggregate. There are multiple metrics that are based upon key social, political and economic indicators that compose this index (see Table 2). The FSI then ranks countries using a Composite Score (CSxxx) where a higher score indicates more inclination of the state towards failure. Many proxy indicators enable states to be placed on the stability spectrum as stable, fragile or failed. A short summary of some indicators used to measure state fragility and failure in the main instrument of this research paper are summarized in Table 2.

States that experience drastic food price fluctuations, economic distortion, disparity and food riots top the list of the FSI and include, Somalia, Chad, Sudan, the Democratic Republic of Congo (DRC), Haiti, Zimbabwe, Afghanistan, Central African Republic, Iraq and Yemen. Food riots across more than two-dozen countries from 2008 to 2012 were the most visible effect of chronic food insecurity, social, political and economic shock [26]. The FSI does not predict state failure but rather describes state fragility based on quantitative and qualitative metrics - the rankings grade states in order of severity of failure.

\subsubsection{Fragile and Failed State Controversy and Limitations}

The FSI is not without controversy or limitations. Some opponents comment that describing state fragility or failure is nothing but an academic exercise when dealing with state security and development in a complex global arena. Opponents also purport that the use of the "failed state" label is inherently political, and based primarily on Western perceptions and security interests [27] [28]. Indeed, identifying or indicating a fragile or failed state comes with risk and can cause unintended damage to a fledgling state as foreign aid and business may flee or local rivalries may attempt to cease power and agitate further civil unrest as opportunists [22].

Despite these proposed academic shortcomings, the key indicators of external pressure and institutional capacity realities in governance found within the FSI, directly relate to food security for their citizens and overall potential for state institutions in improving the food, health and human security environment. In sum, in this paper, fragile and failed states are those that quantitatively top the FSI.

\subsubsection{Global Food Security Index (GFSI)}

The Global Food Security Index (GFSI) 2012, is an assessment of food affordability, availability and quality. The GFSI measures a series of indicators that evaluate present programming, policies and practices that influence food security and ranks 105 countries accordingly [26]. The GFSI uses the working definition of food security, "When people at all times have physical, social and economic access to sufficient and nutritious food that meets their dietary needs for a healthy and active life" (GFSI, 2012). The GFSI ranks countries 1 to 105, where 1 is most food secure (reported as $\mathrm{GFSI}_{\mathrm{R}, \mathrm{SCORE}}$ ). A country score includes the prevalence of undernourishment, stunted and underweight children and the intensity of food deprivation. Each variable showed a negative correlation with the overall scores of 0.70 or greater (not all sovereign nation states are presently listed and are reported as GFSI $\mathrm{NL}_{\mathrm{N}}$-"not listed”).

Table 2. Indicators used to measure state fragility and state failure (adapted from Fund for Peace, 2012 with permission). These metrics are implemented in the methodology of assessing state fragility by the FSI.

\begin{tabular}{|c|c|c|c|}
\hline Social & Economic & Political & Military and Policing \\
\hline Demographic pressure & Uneven economic development & Corruption & Drug trade and illicit economy \\
\hline $\begin{array}{l}\text { Natural disasters and } \\
\text { environmental degradation }\end{array}$ & Access to improved services & Government effectiveness & Human rights and rule of law \\
\hline Disease and public health & Poverty and economic decline & Political participation & Human trafficking \\
\hline Food scarcity, malnutrition & Unemployment & $\begin{array}{l}\text { Water, sanitation, basic } \\
\text { infrastructure and energy }\end{array}$ & Incarceration, torture and executions \\
\hline Mortality & Purchasing power, inflation & Quality healthcare & $\begin{array}{l}\text { Rebel activity, military coups, } \\
\text { bombings }\end{array}$ \\
\hline $\begin{array}{l}\text { Refugee and internally } \\
\text { displaced peoples }\end{array}$ & & $\begin{array}{l}\text { Civil liberties and political } \\
\text { freedoms }\end{array}$ & Foreign military intervention \\
\hline $\begin{array}{l}\text { Human flight and } \\
\text { brain drain }\end{array}$ & & $\begin{array}{l}\text { Internal conflict, riots and } \\
\text { protests }\end{array}$ & $\begin{array}{l}\text { Foreign assistance, peacekeeper } \\
\text { presence }\end{array}$ \\
\hline
\end{tabular}




\section{Analysis}

As short country case studies, the top 10 states from the FSI can each be unpacked within a food security context. Somalia $\left(\mathrm{FSI}_{2012}=1 ; \mathrm{CS}_{114.9} ; \mathrm{GFSI}_{\mathrm{NL}}\right)$ in 2012 experienced famine and lack of access to sustainable food than in the common history of Africa. Somalia not only has a major sociopolitical issue with lack of rule of law, recently seen with piracy on its seas, but also has multiple famine zones where multiple deaths from starvation and dehydration occur daily. Associated morbidity with famine and lack of potable water access with decreased food security occur such as cholera, malaria, poor child development and wasting are rising in both incidence and prevalence. Famine and disease easily dodge borders, neighboring Kenya (FSI $2012=16$; $\mathrm{CS}_{98.4} ; \mathrm{GFSI}_{77,37.6}$ ), Ethiopia $\left(\mathrm{FSI}_{2012}=17 ; \mathrm{CS}_{97.9} ; \mathrm{GFSI}_{100,26.4}\right)$ and Eritrea $\left(\mathrm{FSI}_{2012}=23 ; \mathrm{CS}_{94.5} ; \mathrm{GFSI}_{\mathrm{NL}}\right)$ are at significant risk of not only being affected by similar famine seen in Somalia, and drought, but also by the health crisis that ensues from mass migration flows trans-border as populations attempt to find basic food and water access [29].

Furthermore, Chad $\left(\mathrm{FSI}_{2012}=4, \mathrm{CS}_{107.6} ; \mathrm{GSFI}_{104,20.2}\right.$ ), a landlocked country with no access to its own port, must rely upon neighboring country infrastructure to have adequate access to global markets; along with now fractured Sudan ${ }^{1}\left(\mathrm{FSI}_{2012}=3\right.$ CS $_{109.4} ; \mathrm{GFSI}_{96,27.6}$ ) face a water and food supply crisis, and conflict over mineral rights that has led to food insecurity. The Democratic Republic of Congo (DRC) $\left(\mathrm{FSI}_{2012}=2 ; \mathrm{CS}_{111.2} ; \mathrm{GFSI}_{105,18.4}\right)$ is experiencing an increase in prevalence of poverty and cholera with consequent health insecurity. Chronic conflict disrupts and limits adequate access to water and food [29].

Meanwhile, Haiti,(FSI $2012=7 ; \mathrm{CS}_{104.9} ; \mathrm{GFSI}_{102,24.2}$ ), the only North American state in the top 10 of the FSI, lacks the institutional capacity and resilience to promptly recover from the earthquake of 2010 and has experienced waves of cholera and other waterborne disease, as well as, food insecurity due to heavy reliance on food imports. For example, the humanitarian response has brought on a manmade cholera epidemic that has killed over 7000 people and infected more than 400,000 throughout Haiti [30].

In Zimbabwe $\left(\mathrm{FSI}_{2012}=5 \mathrm{CS}_{106.3} ; \mathrm{GFSI}_{\mathrm{NL}}\right.$ ), lack of transparency, political and financial corruption and instability persist. Food insecurity is greatly impacted through a reduction in ecological integrity, climate related agricultural disruption and a decline in regional food production. Zimbabwe also experiences increased incidence of the vaccine preventable illness measles. Nearby Central African Republic $\left(\mathrm{FSI}_{2012}=10 ; \mathrm{CS}_{103.8}\right.$; $\mathrm{GFSI}_{\mathrm{NL}}$ ), another landlocked country may be unstable due to spillover from neighboring state failure and conflict. Its landlocked status may contribute to a stagnant economy, reliance on food imports, reduced access to food and agriculture infrastructure, increased food costs and decreased food security.

Iraq $\left(\mathrm{FSI}_{2012}=9 ; \mathrm{CS}_{104.3} ; \mathrm{GFSI}_{\mathrm{NL}}\right)$ and Afghanistan $\left(\mathrm{FSI}_{2012}=6 ; \mathrm{CS}_{106.0} ; \mathrm{GFSI}_{\mathrm{NL}}\right)$ have been listed in the top ten of the FSI since its inception and pose increased risks to food security and public health as they are experiencing remnants of war, foreign occupation and transition out of conflict and state destabilization. Both countries face extreme risk of food security due to weak state institutions, fledgling rule of law and quantifiable state fragility experienced by post conflict states. Increasing food price shock strain the financial resources of displaced populations throughout Iraq and in bordering Syria $\left(\mathrm{FSI}_{2012}=23 ; \mathrm{CS}_{94.5} ; \mathrm{GFSI}_{70,42}\right)$, Jordan $\left(\mathrm{FSI}_{2012}=90\right.$; $\mathrm{CS}_{74.8} ; \mathrm{GFSI}_{54,50.6}$ ) and EU applicant Turkey $\left(\mathrm{FSI}_{2012}=85 ; \mathrm{CS}_{76.6} ; \mathrm{GFSI}_{36,63.7}\right)$ with increased migration flow of internally and externally displaced peoples [20]. As remnants of an Arab Spring and conflict throughout Syria play out with significant civilian casualties, food infrastructure and access will continue to experience disruption -as well decreased health security for the pediatric population due to barriers for vaccine preventable illnesses associated with conflict and violence.

Indeed, Syria has considerable destabilizing shocks related to all key indicators of state stability-most notably major migration of people into neighboring Turkey, Iraq and Lebanon, major unemployment, lack of state legitimacy, a factionalized elite, daily acts of war, protests and riots, torture and potential significant human rights abuses. Syria is fragile and many citizens throughout the county are food insecure. The Arab Spring has experienced extensive prolonged crisis with increased violence, considerable mortality, limited foreign intervention and considerable access by the state to a monopoly of violence to ethnically diverse communities. The Syrian agricultural sector is in decline and in some regions halted, due to consecutive years of drought and the impact of conflict; critical inputs such as fertilizer and seed are no longer available and harvests have been disrupted as seasonal workers have found travel to agricultural districts impossible due to basic security [31]. Approximately 3 million Syrians are at risk of food insecurity with strategic crops in a historically largely

\footnotetext{
${ }^{1}$ Sudan is ranked as Sudan and South Sudan on the FSI ${ }_{2012}$, with South Sudan FSI = not ranked; CS $_{108.4 .}$ South Sudan declared independence and was fully recognized as a nation in mid 2011 and was not yet tracked for this index.
} 
self-sufficient and export-earning sector are affected and at risk of further decay [32]. The effect of prolonged conflict and war on the food security and subsequent health security of citizens are still only being elucidated. However, sliding indicators point to significant state fragility and lack of inclusive state institutions engendering equal access to markets, state legitimacy or any sort of infrastructure to promote public health and disease prevention.

Further conflict in Afghanistan highlights challenges to food security and public health in prolonged conflict, oppression of civil society and the NATO occupation force with unclear redeployment timelines or continuity of force. Furthermore, the agricultural practices of planting high profit poppy for illicit street and drugs of abuse to be sold in local and foreign markets, as opposed to, higher caloric yield crops such as rice, wheat and cereals, coupled with an austere environment are leading to a public health crisis and food insecurity for its people [33]. As Afghanistan experiences decades of war and conflict, food price fluctuation and inflation are debilitating to the small farmer. This may lead to many families without adequate access to a consistent and sustainable locally sourced food supply [34]. Food insecurity is multiplied by economic sustainability factors such as inadequate water supply, safe and secure work and working conditions for farmers and education on crop alternatives.

Officially, failed states are not the only at risk counties for food insecurity, the Middle East and North African (MENA) region is a formulaic region of states that rely heavily on imports for grain consumption with finance from internal natural resource extraction (oil, natural gas etc.). Geopolitical instability throughout the MENA region with regime change, protests, riots and significant state sponsored violence prevails. The regime upheavals that previous heads of state Zine el-Abidine Ben Ali in Tunisia, Hosni Mubarak in Egypt and Muammar Al-Qaddafi in Libya may only be the start of social and economic unrest with a major food security component and in some cases, its catalyst. Iran for example $\left(\mathrm{FSI}_{2012}=34 ; \mathrm{CS}_{89.6} ; \mathrm{GFSI}_{\mathrm{NL}}\right)$ has experienced a doubling of its basic foodstuffs import market costs since the summer 2012 round of imposed sanctions, many tied to oil exports and resulting in a collapse of the Iranian Rial, with potential further sanction and state destabilization or foreign military intervention. A summary table of the top 10 fragile states and their corresponding malnourishment and food security rankings are found in Table 3 .

\subsection{Food Security and Nutritional Access}

Food insecurity leads to under-nutrition at the micro and macro nutrient level. This arises not only through access to food markets, food transport and safe environments that encourage food security, but soil itself must also be capable of sustainably producing locally sourced food. Through over-farming lands or by relying on a single crop for export or consumption, the depletion of essential water stores, essential soil elements and overall environmental degradation occurs. Said plainly, the health of the environment drives agriculture. Its success drives commodity markets and pricing, price and demand drives food production, which in turn drives local and international economies of scale.

Table 3. Summary of the FSI, the GFSI and malnourishment against estimated population.

\begin{tabular}{|c|c|c|c|c|c|c|}
\hline Country & $\begin{array}{c}\text { FSI }_{2012} \text { Rank } \\
{[20]}\end{array}$ & $\begin{array}{c}\text { FSI CS }_{2012} \\
\text { (composite score) }\end{array}$ & $\begin{array}{l}\text { GFSI }_{2012} \text { Rank } \\
\text { (1 = best score) }\end{array}$ & $\begin{array}{c}\text { GFSI }_{2012} \text { Score } \\
(100=\text { best score })\end{array}$ & $\begin{array}{c}\text { Malnourishment } \\
\text { Prevalence [32] }\end{array}$ & $\begin{array}{l}\text { Number of Population } \\
\text { (undernourished) }\end{array}$ \\
\hline Somalia & 1 & 114.9 & Not ranked & Not ranked & No data & Unknown \\
\hline $\begin{array}{c}\text { Congo (Democratic } \\
\text { Republic) }\end{array}$ & 2 & 111.2 & 105 & 18.4 & $39 \%$ & 4.1 million \\
\hline Sudan & 3 & 109.4 & 96 & 27.6 & $22 \%$ & 8.8 million \\
\hline Chad & 4 & 107.6 & 104 & 20.2 & $13 \%$ & 0.5 million \\
\hline Zimbabwe & 5 & 106.3 & Not ranked & Not ranked & $57 \%$ & 5.5 million \\
\hline Afghanistan & 6 & 106.0 & Not ranked & Not ranked & $30 \%$ & 3.7 million \\
\hline Haiti & 7 & 104.9 & 102 & 24.5 & No data & No data \\
\hline Yemen & 8 & 104.8 & 83 & 33.3 & $40 \%$ & 1.7 million \\
\hline Iraq & 9 & 104.3 & Not ranked & Not ranked & No data & No data \\
\hline $\begin{array}{l}\text { Central African } \\
\text { Republic }\end{array}$ & 10 & 103.8 & Not ranked & Not ranked & $14 \%$ & 2.9 million \\
\hline
\end{tabular}


Poverty is inversely proportional to food security and directly proportional to state fragility. Chronic under nutrition reduces overall productivity and increases vulnerability to entirely preventable illnesses and in young children, it increases vulnerabilities to chronic illnesses, impairs motor skills, cognitive abilities and economic and social productivity later in life.

Obesity, starvation and micronutrient deficiencies are experienced in both the developed and developing world - a preventable health problem directly linked to food security and food access [35]. When a state experience's low levels of food access and security for it citizens, preventable micronutrient deficiencies and disease can increase. Some examples being Vitamin A (retinol) deficiency leading to vision loss, iron deficiency, leading to anemia and mental development disorders and zinc deficiency, leading to developmental retardation and congenital malformations. On the contrary, when too many calories are consumed without expenditure, over nourishment and obesity can ensure leading to the non-communicable disease explosion with precipitating hypertension, hypercholesterolemia, diabetes, gastrointestinal disorders and cancer.

Unbalanced nutrition, inadequate access to food and food markets, and misappropriation of resources are commonly found within fragile and failed states at the governmental and household levels. These are compounded by inadequate access to nutritious food, arable land, fresh water, sustainable energy, non-toxic fertilizers or adequate farm technology. Another contributing factor is the use of arable land and food crops for biofuel production and energy. All of these factors make increasing global food output extremely difficult. But how does the food market work to enable food security or insecurity?

\subsection{Market Manipulation and the Commoditization of Food Security}

Supply and demand drive commodity prices in the free market-regardless of moral character of the commodity. Without global financial regulation, the commoditization of food, healthcare and other common goods will create a market system where inequality encourages human suffering to maximize revenues [36]. Items that are scarce fetch a higher price, while items in abundance tend to be cheaper. This economic dynamic rings true in fragile and failed states but with potentially disproportionate consequences of price fluctuation and food market access; this may be partially due to the reduced market and institutional resilience. However, making certain goods into pure commodities without limit, can corrupt the very value of these goods and market norms can crowd out valuable nonmarket behavior [37]; market limits need to be explored and made sustainable, not exploited to no limit.

When harvest yields on crops fluctuate, even by small margins, the global effects on food security are long lasting, intensified and encourage market access inequality. The absence of and otherwise ineffective and weak state institutions with poor governance by the state all contribute to this increase in state vulnerability and instability with an obvious market component.

Owing to unknown future crop yields in most types of agriculture, financial instruments have been developed for investors to wager on the future price of many agricultural commodities; this helps offset the economic effects of potential crop losses. If crop yields for a commodity (e.g. wheat and grain) are greater than expected in a certain market, the market price may drop. Conversely, if there is a poor harvest and less grain is reaped, the market price would rise precipitously. In fragile and failed states, market forces can be altered by conflict, war, dysfunctional humanitarian programming or other food aid into a market, corrupt practices and complete breakdown in rule of law and economic infrastructure. This can be seen best with international currency tariffs on outflows of money, closing of banks or not making good on past deposits, collapse of any fledging financial sector and uncontrollable inflation making local currencies worthless. The market manipulation that was seen through commodity markets and traders in recent years has led to soaring prices and food insecurity [38]-[40].

\subsection{Financial Products and Risk}

In 1991, in order to limit risk and maximize the potential profit from uncertain commodity prices, the financial firm of Goldman Sachs developed the Goldman Sachs Commodity Index (GSCI) [41]. In 1999, the Commodity Futures Modernization Act of 2000 (CFMA) deregulated over-the-counter (OTC) financial products or derivatives [42]. This included the commodity market and it enabled investors to engage in commodity trading without limit. An unintended consequence was the development of a food crisis with one billion people at risk. How this arose is described below.

Before the GSCI was constructed, the Commodity Research Bureau (CRB) index functioned to help measure 
the overall direction of commodity sectors. The CRB enabled investors to help assess the financial risks associated with long and short-term investments in agricultural products and commodities. However, the CRB index was less sophisticated than the GSCI, which enabled investors to focus their investments more tightly, and eventually dictate price changes that resulted in considerable price fluctuations, food insecurity and the preventable catastrophe of famine for several regions.

For example, the price of grain was traded between buyers and sellers at its future price-before the bushel had been grown, harvested or valued by that market. This may sound like a questionable wager, but this concept and practice enables price stability in wheat and grain for a loaf of bread. It also allows farmers to hedge investment for times of poor crop yield years and to invest within their own farms and business. Furthermore, these practices help to decrease the price of grain with time and greatly impact decades of public policy, humanitarian aid and enable food security for many countries and markets. These are defining features of a very connected global grain market with many countries still attempting to impose subsidy interventions, which can include land grabs of arable land in poor nations by wealthier nations to farm a myriad of crops for investor countries' food security. These crops, now grown in a poorer nation by wealthy countries and multinational agricultural firms will, due to rising prices, make it to market only in rich states.

The link between the price variability of grain on local and international markets is complex. However, when grain is traded on one of the three major American primary grain exchanges in Chicago, Kansas City or Minneapolis, the price affects global food pricing [40]. Some factors influencing price are weather and conflict. Speculation, also affects price and these factors and market influence can occur in one region and have cascading effects across markets and, ultimately on the price of bread in distant countries. Land rights and equity in access to land can lead to food security across communities and populations.

With this as context, the advent of the GSCI slowly set the stage for great disruption in such a global market by long-term investment in grain with no commitment to food production or mechanism to offset food insecurity. The ability to buy and sell grain commodities, as well as to provide liquidity in the market with actual grain storage and food production, became disconnected. The market was able to treat the future of grain and other commodities on the GSCI similarly to that of a stock or other financial product without having to produce, store or actually sell any grain at all. This was a departure from what grain really is, namely a tangible, agricultural yield in the form of bushels, and it was quickly transformed into an investment product with limitless paper value [43]. But, what happens to the grain market when investors wish to take their money out, and begin placing orders to sell in large volumes? This commodity index, through such a simple process of speculative selling, and buying, led to global skyrocketing grain price shocks.

This new financial product in commodities attracted many investors to consider their investment in grain futures as safe. Although this investment strategy led to significant investments in grain futures, there was no market mechanism to prevent "shorting", or selling, and subsequent extreme fluctuations and instability in price [40]. The GSCI enabled futures to be traded as stocks, with prices linked more to investor interest and greed than to the true value of the commodity. Aggressive and unscrupulous investors seek profit with scalable value; repercussions or market shocks are not considered. In many ways, these investors and speculators view people and the natural environment as a subsidiary of the economy and only as a tool for enrichment. Investors hold no duty of care and hold no responsibility for any consequences of their trading.

Viewing the natural world as a venue purely for profiteering, and choosing not to observe the negative and catastrophic consequences of limitless profit has led to the destruction of natural ecosystems and a health security void throughout many regions. Agriculture should not be a servant of economic growth, but rather a foundational source of social and ecological sustainability that encourages food security and stability [44]. Investor sentiment of profiting from commodities is not sustainable and there are inherent biophysical limits of the global ecosystems [45]. The GSCI precipitated food insecurity for over one billion people.

This was particularly apparent during the financial crises of 2007-2008 when investors sold their stocks and put it into gold and grain, thus driving their prices to new heights. Grain and many other commodities, were seen as safer investments to park capital than other risky products such as mortgage-backed securities. In market terms, the endless competition to maximize crop yields, especially in wheat, and to enable basic food security to support health, faced the investment banker who artificially increased the price of grain and coordinated a manmade and preventable food crisis. Put simply, if the price of grain was rising considerably, poor country markets would profit more by selling grain to wealthier nations rather than on local markets for local consumption—an unsustainable model. 
Market manipulation occurs globally. However, it is impossible to track the people that are responsible and to hold anyone accountable when famine results. With the advent of market speculation buying and computer assisted trading, these risks increase rapidly. The consequences of economic misadventure can be disastrous and irreparable on a global health, social, economic and environmental scale. Nation-states must already have some level of institutional capacity in order to be prepared for market fluctuations and have rule of law to oppose the myriad of arenas of direct foreign financial intervention, abuse and cronyism.

\subsection{Food Pricing and Insecurity}

When a country relies too heavily on foreign food production or raw wheat as an import, a doubling in the price of wheat or any slight fluctuation in price can send tidal waves throughout the economy and send its citizens to the streets in search of food security [46]. Armed conflict is a key indicator and potential consequence of the failure of states to deal effectively with food price shocks; it also increases the vulnerability of states, communities and households leading to further food insecurity. States can be fragile as a result of underlying political, social and economic factors, and not just weak institutions.

Global food systems have become highly politicized and grossly distorted through manipulation at regional and international levels; however, supply and demand still holds true with agricultural products such as grain and wheat (and many others). What this means is that at market, food and grain suppliers sell to the highest bidder or to those consumers that have prior contracts and arrangements for long term and stable purchases (governments etc.) and the price is not only affected by the number of orders but also through market distortion, country level subsidization and economic arbitration across borders-the purchase of cheap product in one country, to sell for profit in another country and in another market. Price fluctuations in the market have been influenced by factors such as grain-fed beef cattle for human consumption and grain crops grown for biofuels and not for human food [47] [48]. These are examples of "food affluence"; where the price of food is not a key determinant to purchase the food. Most humans do not enjoy this luxury.

The consequences and negative impacts of a rise in the price of food are not felt equally across markets [49]. People who spend a large proportion of their income on food, such as in Egypt $\left(\mathrm{FSI}_{2012}=31 ; \mathrm{CS}_{90.4} ; \mathrm{GFSI}_{52,51.6}\right)$, Indonesia $\left(\mathrm{FSI}_{2012}=63 ; \mathrm{CS}_{80.6} ; \mathrm{GFSI}_{64,46.8}\right)$ and Ukraine $\left(\mathrm{FSI}_{2012}=113 ; \mathrm{CS}_{67.2} ; \mathrm{GFSI}_{44,58.4}\right)$, feel the effects of a relatively small rise in the futures price of food far more than those living where food-costs are relatively low and stable per household, currently found throughout most of Europe and North America-countries that comprise the top 20 of the GFSI including Japan and Australia.

To gauge food price variability across the globe, the Food and Agriculture Organization (FAO) of the United Nations monitors the monthly change in international prices of a basket of food commodities [50]. It is called the "FAO Food Price Index" (FFPI) and is a weighted average of the commodity group price indices of meat, dairy, cereals, oils and fats, and sugar. The FFPI helps gauge food security across the globe; it results in numerical "points" based on pricing in each commodity field. In 2000, the FFPI was 90; in 2007 it was 159, and it peaked in 2008 at 200 points when the most recent food crisis hit. In June 2011, it was reported at 234 [50]. With newly designed specialized commodity investment products that treat commodities similar to that of stocks, this FFPI value helped speculators and investors become ever more interested in using food as an investment product despite drastic consequences to the world's poor [51]. This is investment strategy and practices are contributing factors to food insecurity in fragile and failed states.

Commodity prices are not the only indicators of food security; hunger and malnourishment are as well. Malnourishment is tracked by this index and the correlating values to that of the FSI as found previously in Table 3.

While the FAO collects and analyses global agricultural data and provides technical assistance, there is no organized effort to ensure the adequacy of world food supplies or food security [49]. Indeed, within the last decade, major investment bank interest rates have risen sharply with that of food prices and commodity indices as market volatility, geopolitical and other socio-economic factors make food a speculative and high yield and stable investment. However, this "investment product” and its variation in price can greatly reduce food security and lead to preventable public health crisis that no investor has any obligation or responsibility to consider that hold any duty of care to mitigate.

\section{Policy Solutions: Creating Food Security by Fixing Failed States}

There is no broad-spectrum antibiotic or policy cocktail to increase food and consequent health security in fra- 
gile and failing states. However, the underlying thread throughout such policy must purport that by resuscitating failed states and preventing failure in fragile states, health and food security will increase directly to that of institutional capacity and state health. If there is an increase in state stability, there is a potential increase in health and food security. The integration of development policy of fragile and failed states with that of public health and food programming must be interdisciplinary and defines the nexus of health security.

The theoretical components of state resuscitation must increase state transparency, free but soberly regulate economic and financial systems that can withstand impact and exhibit resilience mechanisms; increase democratic institutions through social and civic organizations, the practical components of rule of law and contracts and widening government capacity and its control of violence. Financial and market system reform in commodities is needed within states and globally tore-calibrate how food aid is given and to ensure there is a sustainable development focus.

Sustainable development is equitable and focuses on increasing living standards across communities and populations. Contrary to extractive institutions, sustainable development does not rapidly diminish natural resources, human capital or otherwise cause creative destruction [13] [52] [53]. Institutions across states encompass multiple processes within conflict and must be inclusive; institutions uphold accepted rules in society and are the humanly devised constraints that shape human interaction, notably in public policy [52] [54] [55]. Food security is directly proportional to that of state stability and food insecurity to that of state fragility and failure.

Humanitarian aid and development is in a state of paradigm shift with one force pushing for the growth of new sources of aid and loans from high and middle income countries, private capital and charitable organizations while the other side focuses on the rights of individuals and advocacy of at risk populations and communities. It must be noted that any solution to the food security problem cannot include simply sending food as aid. This is not an entirely possible, credible or evidenced-based policy that has proven effective or reproducible to assist with fragile or failed states or in helping to build any sustainable model to prevent the next crisis [56][58].

It is our conclusion that resource poor countries can no longer rely on outside aid for public health support and state stability ambitions. Humanitarianism that supports food aid is in a state of debacle as global financial crisis has challenged the archetype of donor financial support and subsequent operation; sustainability is not integrated into this old model of aid of simply giving without accountable obligation [54] [56]. Encouraging and reducing barriers to further public-private partnerships in development and aid policies, could motivate and draw on the risk-taking capital of philanthropy to diagnose market inefficiencies and help build state institutional capacity of enterprises to make nation-states investment ready and economically viable. By encouraging inclusive institutional support at the public health level, by preventing extractive governmental and non-democratic mechanisms, by promoting institutional capacity building and self-directed growth that reduces risk of state failure, it is possible that a sustainable state stability model can ensue and can engender health security feed the positive feedback loop to further solidify state stability.

Strengthening inclusive and democratic foundations of governance, accelerating sustainable economic growth through aid and financial regulation that supports enterprise but does not allow human incentive to commoditize without limit of basic goods; improving basic health metrics of citizens through sanitation and primary healthcare access (highlighting preventative medicine in the form of vaccines)and consolidating the use and control of violence to the state, limiting or removing destabilizing non-state actors and professionalizing security forces must be policy drivers.

For example, certain states, regional communities and households will need immediate food assistance in the midst of a food crisis emergency; however, fragile and failed states require assistance prior to, as presentation, such major shocks to reduce risk and increase state institution capacity slowly, in effect primary prevention at the state aid level. Early warning systems that focus on food and health related metrics such as malnourishment and infectious disease incidence and treatment compliance, as well as food price variability, can assist the prioritization of aid from donors in both the public and private sector [59]. Such early warning systems, such as the FSI, can quickly triage and identify those states that are threatened with food availability problems, food access and balanced consumption. At a very practical, local and operational level, this means reorienting food assistance and humanitarian programs to highlight vulnerability of food insecure states and focusing more on prevention before crisis hits.

The approach of the European Commission (EC) revolves around attempts to reconstruct state capacities in fragile states through technocratic measures leaving fundamental problems of state corruption, ethnic relations, 
human rights and inequality out of reach [60]. The United States focuses much of its development policy through the United States Agency for International Development (USAID); to include a wide batch of programs to health and food assistance that are multifaceted. Overall, what is needed is preventative diplomacy, encouraging fragile states to reverse direction through economic sanction and soft power- to encourage democratic, sustainable and accepted governmental policy practices that will reverse fragile states and mitigate failure.

Agriculturally, increasing sustainability through small-farmer rights, developing regionally specific agricultural methods that increase provision of food market access at the local market level and legitimate sustainability, seed-exchanges, micro-finance focusing on the farming sector are required [44]. Prevention in the form of education for at-risk communities in fragile and failed states is needed to avoid misguided family and household expenditures on poorly nutritious food and other superfluous purchases that are not directly linked to their own health and food security. Key policy shift to securing food security and consequent public health rests on supporting fragile states, resuscitating failed states and guaranteeing rule of law.

A summary of the basic policy initiatives proposed to resuscitate fragile and failed states are found in Table 4.

\section{Conclusions}

Our review and analysis have found that public health within states is directly linked to that of state stability and food security. Food and health security is dictated by state stability, resilience to geopolitical, economic and health shocks. Fragile and failed states are highly vulnerable to shocks and are at risk of extreme poverty, war and chronic conflict. These states lack inclusive institutions and basic state mechanisms that engender stability and reduce barriers to securing public health and food security for their citizens. Fragile and failed states have a lower threshold to conflict and war, experience corrupt financial regimes and are influenced by skewed global market systems that decrease food and health security for the short and long term.

Food security correlates with health security and is dictated by state stability. Building state institutional capacity leads to economic, social and political stability, which feeds positively to induce further state stability, food security and health security. Market reforms and resuscitating fragile and failed states by capacity building of state institutions, encouraging sustainable agriculture and a overturning of the status quo to a more sustainable environment can increase food security.

\section{Table 4. Policy Solution Summary-Fixing failed states and engendering food and health security.}

- $\quad$ Prevention of fragile states falling into failure, preventative diplomacy that encourage inclusive institutions and the triage of fragile and failed states in global development agendas

- International Community support for governments that support rule of law, security, basic policing, public health, multilateral governmental treaties and ethical and transparent governmental and banking practices

- State supported safety nets to alleviate food insecurity through food programming (sustainable in the short term-not to encourage dependency)

- Sustainable food aid through agricultural, technological and sustainable practices with educational access

- $\quad$ Predictable, transparent and partnership oriented private sector policy involvement

- $\quad$ Preparation to tackle the expected impacts of market manipulation and price shocks

- Multilateral stakeholder policy that encourages investment that encourage environmental integrity, environmental infrastructure and environmental protection

- Strengthening and supporting basic public health and hygiene infrastructure to citizens — to include primary healthcare access in the basic form of vaccines and potable water

- $\quad$ Encourage democratic, sustainable and governmental policy that reverse fragile states and mitigate state failure

- Institutional capacity building to increase resilience and adaptations to market and social shock

- $\quad$ Building institutional capacity to manage environmental, economic and political shocks

- Encouraging stability on both the short and long term to rule of law, institutional capacity building and democracy [54]

- Food industry targets for under nutrition

- Increase in public-private development 


\section{Disclosures}

This paper was in part funded by a grant by Institute of Economic Studies, Faculty of Social Sciences, Charles University in Prague and is dedicated to GAUK/910892. All authors have contributed equally to the research, drafting and finalizing of the manuscript.

\section{References}

[1] Hinrichs, C.C. (2012) Regionalizing Food Security? Imperatives, Intersections and Contestations in a Post-9/11 World. Journal of Rural Studies, 29, 7-18.

[2] Newman, E. (2009) Failed States and International Order: Constructing a Post-Westphalian World. Contemporary Security Policy, 30, 421-443. http://dx.doi.org/10.1080/13523260903326479

[3] Kitissou, M. (2014) Africa South of the Sahara 2008-2011: Hunger as a Factor in Political Instability. The Journal of Pan African Studies, 6, 187-195.

[4] Messer, E. and Cohen, M.J. (2007) Conflict, Food Insecurity and Globalization. Food, Culture and Society, 10, 297315.

[5] Kemp, G. (2014) Scarcity and Strategy. Foreign Affairs, 56, 376.

[6] Ng, N. and Prah Ruger, J. (2011) Global Health Governance at a Crossroads. Global Health Governance, 3, 1-35.

[7] Labonté, R. and Gagnon, M. (2010) Review: Framing Health and Foreign Policy: Lessons for Global Health Diplomacy. Globalization and Health, 6, 14. http://dx.doi.org/10.1186/1744-8603-6-14

[8] Kent, G. (2005) Freedom from Want: The Human Right to Adequate Food. Georgetown University Press, Washington DC.

[9] Aldis, W. (2008) Health Security as a Public Health Concept: A Critical Analysis. Health Policy Planning, 23, 369-375. http://dx.doi.org/10.1093/heapol/czn030

[10] Chiu, Y.W., Weng, Y.H., Su, Y.Y., Huang, C.Y., Chang, Y.C. and Kuo, K.N. (2009) The Nature of International Health Security. Asia Pacific Journal of Clinical Nutrition, 18, 679-683.

[11] Macrae, J. (1996) Purity or Political Engagement?: Issues in Food and Health Security Interventions in Complex Political Emergencies. Proceedings of UNU-WIDER \& QEH Project Meeting on the Political Economy of Humanitarian Emergencies, Helsinki, 6-8 October 1996.

[12] Patrick, S. (2011) Weak Links: Fragile States, Global Threats and International Security. Oxford University Press, New York.

[13] Collier, P. (2007) The Bottom Billion: Why the Poorest Countries Are Failing and What Can Be Done about It. Oxford University Press, Oxford.

[14] Hotez, P.J. (2008) Forgotten People, Forgotten Diseases: The Neglected Tropical Diseases and Their Impact on Global Health and Development. ASM Press, Washington DC.

[15] Catalano, R. (1991) The Health Effects of Economic Insecurity. American Journal of Public Health, 81, 1148-1152.

[16] Paris, R. (2001) Human Security: Paradigm Shift or Hot Air? International Security, 26, 87-102. http://dx.doi.org/10.1162/016228801753191141

[17] Zoellick, R. (2008) Fragile States: Securing Development. Survival, 50, 67-84.

[18] Gros, J.-G. (1996) Towards a Taxonomy of Failed States in the New World Order: Decaying Somalia, Liberia, Rwanda and Haiti. Third World Quarterly, 17, 455-471.

[19] Rotberg, R.I. (2003) State Failure and State Weakness in a Time of Terror. World Peace Foundation, New York.

[20] The US Fund for Peace (2012) Failed States Index 2011. The Fund for Peace Publication, Washington DC.

[21] Rotberg, R.I. (2004) When States Fail: Causes and Consequences. Princeton University Press, Princeton.

[22] Patrick, S. (2006) Weak States and Global Threats: Assessing Evidence of Spillovers. Center for Global Development Working Paper No. 73.

[23] Naim, M. (2005) Illicit: How Smugglers, Traffickers and Copycats are Hijacking the Global Economy. Doubleday Press, New York.

[24] Zartman, I.W. (2005) Cowardly Lions: Missed Opportunities to Prevent Deadly Conflict and State Collapse. Lynne Rienner Publisher, London.

[25] Bomann-Larsen, L. and Wiggen, O., Eds. (2004) Responsibility in World Business: Managing Harmful Side-Effects of Corporate Activity. United Nations University Press, Tokyo.

[26] Alarcon, D., Deoudes, G., Joehnk, T.F., Jordan, K., Kim, S., Lai, V., Minkovski, P. and Powell, R. (2012) Global Food 
Security Index 2012: An Assessment of Food Affordability, Availability and Quality. The Economist Intelligence Unit, London.

[27] Boas, M. and Jennings, K.M. (2005) Insecurity and Development: The Rhetoric of the "Failed State". The European Journal of Development Research, 17, 385-395.

[28] Call, C. (2011) Beyond the "Failed State": Toward Conceptual Alternatives. European Journal of International Relations, 17, 303-326.

[29] Zolnikov, T.R. (2013) The Maladies of Water and War: Addressing Poor Water Quality in Iraq. American Journal of Public Health, 103, 980-987. http://dx.doi.org/10.2105/AJPH.2012.301118

[30] US Agency for International Development (USAID) Earthquake and Cholera Fact Sheet \#11, Fiscal Year (FY) 2011. US Agency for International Development, Washington DC.

[31] UN Office for the Coordination of Humanitarian Affairs (OCHA) (2012) Humanitarian Bulletin: Syria. Issue 5, 20 July -03 August 2012.

[32] Food and Agricultural Organization of the United Nations (FAO), World Food Program (WFP) and the Syrian Ministry of Agriculture and Agrarian Reform (SMAAR) (2012) Joint Rapid Food Security Needs Assessment (JRFSNA): Arab Republic.

[33] Famine Early Warning Systems Network (FEWS NET) (2011) Afghanistan-Food Security Outlook July to December 2011. Washington DC. http://reliefweb.int/sites/reliefweb.int/files/resources/Full_Report_1902.pdf

[34] Zyck, S. (2011) Afghanistan: Review Comprehensive Information on Complex Crises. Civil-Military Fusion Centre.

[35] Maher, D., Ford, N. and Unwin, N., (2012) Priorities for Developing Countries in the Global Response to Non-Communicable Diseases. Globalization and Health, 8, 14. http://dx.doi.org/10.1186/1744-8603-8-14

[36] Bryceson, D.F. (1989) Nutrition and the Commoditization of Food in Sub-Saharan Africa. Social Science \& Medicine, 28, 425-440. http://dx.doi.org/10.1016/0277-9536(89)90098-1

[37] Sandel, M.J. (2012) What Money Can’t Buy: The Moral Limits of Markets. Farrar, Straus and Giroux, New York.

[38] Conceicao, P. and Mendoza, R.U. (2009) Anatomy of the Food Crisis. Third World Quarterly, 30, 1159-1182. http://dx.doi.org/10.1080/01436590903037473

[39] Harvey, P. (2009) Social Protection in Fragile States: Lessons Learned. In: Promoting Pro-Poor Growth: Social Protection, OECD, Paris, 183-199.

[40] Kaufman, F. (2011) How Goldman Sachs Created the Food Crisis. Foreign Policy, 19 May 2011.

[41] Erb, C.B. and Harvey, C.R. (2006) The Strategic and Tactical Value of Commodity Futures. Financial Analysts Journal, 62, 69-97. http://dx.doi.org/10.2469/faj.v62.n2.4084

[42] Baker, C.M. (2010) Regulating the Invisible: The Case of Over-the-Counter Derivatives. Notre Dame Law Review, 85, 1287.

[43] Levin, C. and Coburn, T. (2009) Excessive Speculation in the Wheat Market. Majority and Minority Staff Report, Permanent Subcommittee on Investigations, United States Senate.

[44] McMichaela, P. and Schneidera, M. (2011) Food Security Politics and the Millennium Development Goals. Third World Quarterly, 32, 119-139.

[45] Daly, H. (2005) Economics in a Full World. Scientific American, 293, 100-107.

[46] Clapp, J. (2009) Food Price Volatility in the Global South: Considering the Global Economic Context. Third World Quarterly, 30, 1183-1196. http://dx.doi.org/10.1080/01436590903037481

[47] Sage, C. (2012) The Interconnected Challenges for Food Security from a Food Regimes Perspective: Emergency, Climate and Malconsumption. Journal of Rural Studies, 28, 1-10.

[48] Southgate, D. (2009) Population Growth, Increases in Agricultural Production and Trends in Food Prices. The Electronic Journal of Sustainable Development, 1.

[49] Brown, L. (2011) The New Geopolitics of Food: From the Middle East to Madagascar, High Prices Are Spawning Land Grabs and Ousting Dictators. Welcome to the 21st-Century Food Wars. Foreign Policy, 53-62.

[50] Food and Agriculture Organization of the United Nations, FAO (2011) State of Food Insecurity in the World. Corporate Document Repository, Rome. http://www.fao.org/docrep/014/i2330e/i2330e.pdf

[51] Ruitenberg, R. (2011) World Food Prices Climb to Record as UN Sounds Alarm on Further Shortages. Bloomberg, New York.

[52] Acemoglu, D. and Robinson, J.A. (2012) Why Nations Fail: The Origins of Power, Prosperity and Poverty. Profile Books, London.

[53] Stiglitz, J. (2006) Making Globalization Work. Norton, New York, 44. 
[54] Alinovi, L., Hemrich, G. and Russo, L. (2007) Addressing Food Insecurity in Fragile States: Case Studies form the Democratic Republic of the Congo, Somalia and Sudan. ESA Working Paper No. 07-21, July 2007, Agricultural Development Economics Division (ESA), The Food and Agriculture Organization of the United Nations.

[55] North, D. (1990) Institutions, Institutional Change and Economic Performance. Cambridge University Press, Cambridge. http://dx.doi.org/10.1017/CBO9780511808678

[56] Moyo, D. (2011) Dead Aid: Why Aid Is Not Working and How There Is a Better Way for Africa. Farrar, Straus and Giroux, New York.

[57] Seybolt, T. (2009) Harmonizing the Humanitarian Aid Network: Adaptive Change in a Complex System. International Studies Quarterly, 53, 1027-1050. http://dx.doi.org/10.1111/j.1468-2478.2009.00567.x

[58] Fleck, R. and Kilby, C. (2009) Changing Aid Regimes? US Foreign Aid from the Cold War to the War on Terror. Journal of Development Economics, 91, 185-197.

[59] Baliamoune-Lutz, M. and McGillivary, M. (2008) State Fragility: Concept and Measurement. World Institute for Development Economic Research (UNU-WIDER), Research Paper No. 2008/44.

[60] Houta, W. (2010) Between Development and Security: The European Union, Governance and Fragile States. Third World Quarterly, 31, 141-157. 
Scientific Research Publishing (SCIRP) is one of the largest Open Access journal publishers. It is currently publishing more than 200 open access, online, peer-reviewed journals covering a wide range of academic disciplines. SCIRP serves the worldwide academic communities and contributes to the progress and application of science with its publication.

Other selected journals from SCIRP are listed as below. Submit your manuscript to us via either submit@scirp.org or Online Submission Portal.
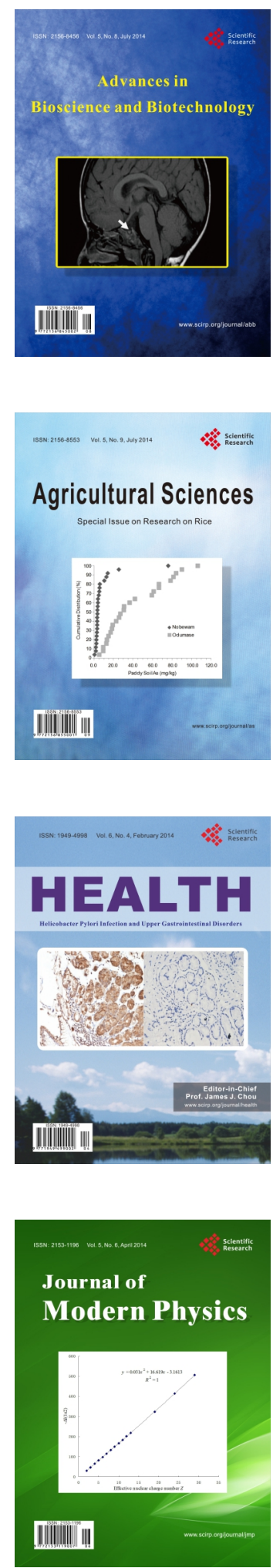
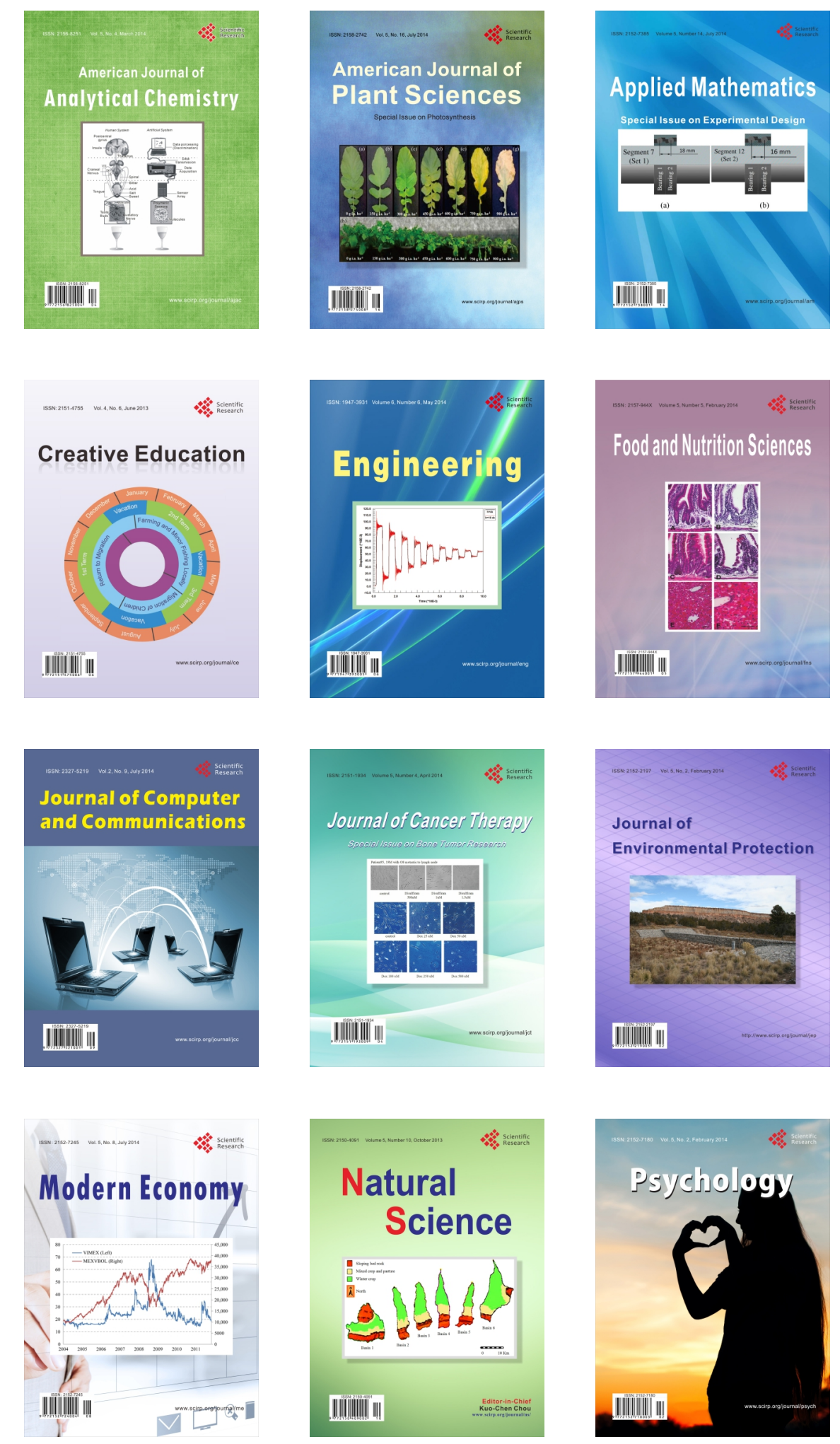